Vol. 5, No. 1, 2021

\title{
PENGARUH KARAKTERISTIK PERUSAHAAN KAWASAN BERIKAT TERHADAP KEUNTUNGAN PERUSAHAAN (STUDY KASUS PADA KPPBC XYZ)
}

\author{
Marsanto Adi Nurcahyo ${ }^{1}$, Aditya Subur Purwana ${ }^{2}$ \\ 1,2 Jurusan Kepabeanan Cukai, Politeknik Keuangan Negara STAN \\ Email: marsanto.adi@pknstan.ac.id
}

\section{INFORMASI ARTIKEL}

Tanggal masuk

[06-03-2021]

Revisi

[29- 03-2021]

Tanggal terima

[26-05-2021]

\begin{abstract}
:
In promoting industrial development, the provision of bonded zone customs facilities is expected to affect the company's finances, one of the indicators is profit, because of the tax exemption, the company can reduce costs. This study aims to analyze the effect of the characteristics of bonded zone companies on the profits whether they are the same or different, what characteristics companies will get maximum profits. This study used secondary data acquired from KPPBC XYZ in 2018. The type of data is in the form of a cross section with a sample used by 55 companies out of 72 . The data is categorical with nominal and ordinal data scales. The analysis used descriptive, One-way analysis of variance (ANOVA) and Tukey HSD or Bonferroni advanced test. Descriptive analysis shows that most bonded zone companies gain profits, both from the type of industri, investment, duration, level of export and exemption. Based on the factorial analysis test results, there are differences in the effect of the type of investment and duration on company profits. Meanwhile, the effect of other variables is the same. Based on the Bonferroni test, mixed investment has a bigger positive effect than domestic investment and foreign investment on company profits. The duration of 1-2 years and 2-3 years have a greater influence on company profits.
\end{abstract}

\begin{abstract}
ABSTRAK:
Dalam mendorong pengembangan industri, pemberian fasilitas kepabeanan kawasan berikat diharapkan berpengaruh terhadap keuangan perusahaan, salah satu indikatornya adalah keuntungan. Adanya pembebasan perpajakan akan mengurangi cost perusahaan. Penelitian ini bertujuan untuk menganalisis pengaruh karakteristik perusahaan kawasan berikat terhadap keuntungan, apakah sama besar atau berbeda, dan karakteristik perusahaan seperti apa yang mendapat manfaat keuntungan terbesar. Penelitian ini menggunakan data sekunder dari KPPBC XYZ pada tahun 2018. Jenis data berupa cross section dengan sample yang digunakan 55 dari 72 perusahaan. Data bersifat kategori dengan skala data nominal dan ordinal. Analisis menggunakan deskriptif, one-way analysis of variance (ANOVA) dan uji lanjut Tukey HSD atau Bonferroni. Analisis deskriptif menggambarkan sebagian besar perusahaan kawasan berikat memperoleh manfaat berupa keuntungan perusahaan, baik dari jenis industri, jenis investasi, umur fasilitas, tingkat ekspor dan tingkat pembebasan. Berdasarkan hasil pengujian analisis faktorial, terdapat perbedaan pengaruh jenis investasi dan umur fasilitas terhadap keuntungan perusahaan. Sementara itu, pengaruh variabel lainnya sama. Berdasarkan uji Bonferroni, investasi campuran mempunyai pengaruh lebih besar positif dibandingkan investasi dalam negeri dan investasi asing terhadap keuntungan perusahaan. Umur fasilitas 1-2 tahun dan 2-3 tahun memberikan pengaruh lebih besar terhadap keuntungan perusahaan.
\end{abstract}

Kata Kunci: Analisis Faktor, Fasilitas Kepabeanan, Karakteristik Perusahaan, Kawasan Berikat, Keuntungan Perusahaan. 
Keywords: Bonded Zone, Company Characteristics, Customs Facilities, Company Profits, Factor Analysis.

\section{PENDAHULUAN}

Perdagangan internasional merupakan kegiatan yang tidak terhindarkan pada setiap negara di dunia saat ini. Negara mempunyai kesempatan untuk mendapatkan jenis barang yang lebih beragam, biaya perolehan yang lebih rendah, transfer teknologi dan meningkatkan kompetisi (Mankiw, 2016). Negara akan berusaha untuk memenangkan kompetisi dengan mendorong produk dalam negeri dapat bersaing di pasar internasional.

Negara dapat memberikan fasilitas kepada industri agar dapat bersaing dengan industri lain di luar negeri. Fasilitas dapat berupa proteksi maupun subsidi. Fasilitas yang lazim diberikan berupa pengurangan tarif pajak dalam rangka impor bahan baku untuk industri. Selain itu, negara juga memberikan proteksi industri dengan mengenakan pembatasan pada impor barang tertentu yang dapat mengganggu pasar dalam negeri.

Terhadap industri yang bertujuan ekspor, negara memberikan fasilitas pada impor bahan baku. Pengolahan bahan baku menjadi barang jadi yang bertujuan ekspor diberikan pembebasan atau tidak dipungut pajak. Dengan begitu, diharapkan industri mendapatkan keuntungan lebih karena tidak perlu membayar pajak saat impor bahan baku. Dengan keadaan tersebut, produk dapat lebih bersaing dengan produksi dari negara lain.

Fasilitas tersebut dinamakan kawasan berikat yang diberikan oleh Direktorat Jenderal Bea Cukai (DJBC). Dalam fasilitas tersebut diberikan penangguhan atas bea masuk barang impor dan tidak dipungut pajak pertambahan nilai (PPN) dan pajak penghasilan $(\mathrm{PPh})$ impor. Fasilitas diberikan dalam kegiatan impor bahan baku yang akan diolah dalam kawasan berikat.

Fasilitas kawasan berikat diberikan untuk meningkatkan investasi dan ekspor serta mengembangkan industri nasional ${ }^{1}$. Permberian fasilitas tersebut diharapkan mampu mendorong investasi di dalam negeri dan juga ekspor sehingga mampu meningkatkan devisa bagi negara.

Beberapa penelitian terdahulu tentang dampak kawasan berikat, diantaranya

\footnotetext{
${ }^{1}$ Peraturan Menteri Keuangan No

131/PMK.04/2018 tentang Kawasan Berikat
} 
dilakukan oleh Valentina (2019), yang menyimpulkan bahwa perusahaan kawasan berikat mampu memperbaiki cash flow dan menurunkan jumlah prepaid tax yang harus dibayarkan. Sementara itu, penelitian yang dilakuan oleh Octarina (2015), mengemukakan bahwa fasilitas kawasan berikat menunjukkan pengaruh yang positif terhadap perkembangan suatu perusahaan. Penelitian yang dilakukan oleh Adiyanti (2012), menyatakan bahwa fasilitas perpajakan pada kawasan berikat mampu meningkatkan nilai ekspor pada perusahaan. Dari penelitian terdahulu tersebut, dapat disimpulkan bahwa terdapat pengaruh positif kawasan berikat terhadap cash flow, peningkatan nilai ekspor dan perkembangan perusahaan.

Namun, dalam penelitian yang dilakukan Khizazi (2020), diketahui bahwa terdapat $20 \%$ perusahaan kawasan berikat yang menjadi objek penelitiannya mengalami kerugian. Hal ini menjadi sebuah pertanyaan besar mengapa terdapat perusahaan kawasan berikat yang mendapatkan insentif bea masuk dan tidak dipungut pajak, tetapi tidak mendapatkan keuntungan (profit).

Berdasarkan penelitian-penelitian di atas terbukti secara empiris bahwa perusahaan penerima fasilitas kawasan berikat mendapatkan manfaat, di antaranya berupa manfaat keuangan. Dengan kata lain, kawasan berikat berpengaruh terhadap keuntungan perusahaan. Namun, penelitian-penelitian tersebut tidak menyertakan karakteristik perusahaan penerima fasilitas kawasan berikat. Oleh karena itu, penelitian ini akan melakukan analisis karakteristik perusahaan penerima fasilitas kawasan berikat terhadap. Karakteristik yang menjadi tujuan penelitian yaitu apakah pengaruh karakteristik perusahaan kawasan berikat terhadap keuntungan sama besar atau berbeda. Jika berbeda, perusahaan dengan karakteristik seperti apa yang mendapat manfaat keuntungan terbesar. Sepanjang pengetahuan penulis, masih terbatas penelitian yang mengukur dampak kebijakan fasilitas kepabeanan pada perusahaan. Sebagian besar penelitian mengukur pengaruh fasilitas tersebut pada perekonomian secara umum.

Berdasarkan latar belakang tersebut, pertanyaan penelitian yang dirumuskan adalah, apakah karakteristik perusahaan penerima fasilitas kawasan berikat pengaruhnya sama atau berbeda terhadap keuntungan perusahaan; dan/atau karakteristik perusahaan kawasan berikat mana yang memberikan keuntungan berbeda/lebih besar. Karakteristik 
perusahaan diukur dari beberapa variabel, yaitu:

1. jenis industri penerima fasilitas. Data berjenis kategorik dengan skala data nominal (kelompok) yang terdiri dari garmen, tekstil, sepatu/kulit dan plastik/aksesoris/cetakan;

2. jenis investasi perusahaan penerima fasilitas. Data berjenis kategorik dengan skala data ordinal (kelompok dan peringkat) yang terdiri dari investasi dalam negeri, campuran dan asing.

3. umur pemberian fasilitas. Data berjenis kategorik dengan skala data ordinal (kelompok dan peringkat) yang terdiri dari $\leq 1$ tahun, 1-2 tahun, 2-3 tahun dan $>3$ tahun.

4. tingkat ekspor perusahaan penerima fasilitas. Data berjenis kategorik dengan skala data ordinal (kelompok dan peringkat) yang terdiri dari eskpor $\leq 50 \%$, $50 \%<$ ekspor $\leq 75 \%$, $75 \%<$ ekspor $\leq 99 \%$, dan $100 \%$ ekspor.

5. nilai pembebasan. Data berjenis kategorik dengan skala data ordinal (kelompok dan peringkat) yang terdiri dari kelompok persentase nilai pembebasan terhadap nilai ekspor, yaitu $\quad$ pembebasan $\leq 20 \%$, $20<$ pembebasan $\leq 40 \%$, pembebasan $>40 \%$.

Tujuan penelitian yang hendak dicapai sebagaimana pertanyaan penelitian yaitu menganalisis karakteristik perusahaan penerima fasilitas kawasan berikat, apakah pengaruhnya sama atau berbeda terhadap keuntungan perusahaan dan/atau karakterisktik perusahaan kawasan berikat mana yang memberikan keuntungan berbeda/lebih besar.

Gambar I.1: Framework Penelitian 
Vol. 5, No. 1, 2021

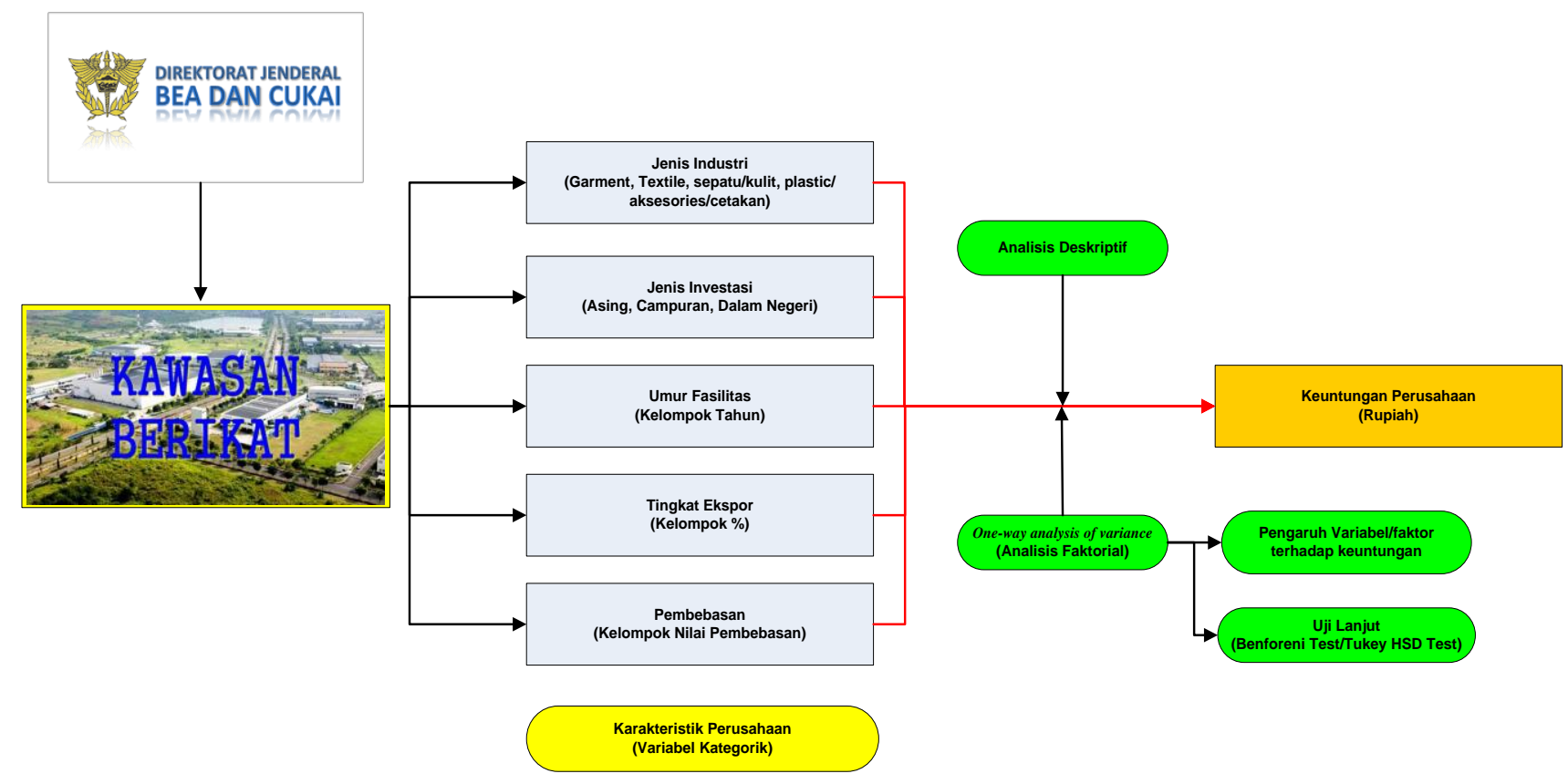

Sumber: diolah penulis

Berdasarkan uraian di atas, Namun, terdapat keterbatasan bahwa data framework penelitian ini seperti pada yang digunakan hanya data studi kasus gambar I.1, yaitu karakteristik perusahaan dari salah satu Kantor Bea Cukai. penerimaan fasilitas kawasan berikat yang diukur dengan variabel berjenis kategorik (dengan skala nominal maupun ordinal) berupa jenis industri, jenis investasi, umur fasilitas, tingkat ekspor dan tingkat Walaupun KPPBC XYZ termasuk sepuluh besar jumlah kawasan berikat yang diawasi, akan lebih detail jika menggunakan data seluruh kawasan berikat yang ada di Indonesia.

pembebasan berdampak pada keuntungan perusahaan. Hipotesis awal yaitu:

$\mathrm{H}_{0}$ : Pengaruh setiap kategori variabel dalam karakteristik perusahaan berikat sama, terhadap keuntungan perusahaan.

$\mathrm{H}_{1}$ : Minimal ada satu pengaruh dalam setiap kategori variabel dalam karakteristik perusahaan berikat berbeda terhadap keuntungan perusahaan.

Penelitian telah dilakukan

\section{KAJIAN LITERATUR}

\section{a. Teori Perdagangan Internasional}

Konsep keunggulan komparatif yang dikemukakan oleh David Ricardo merupakan model perdagangan internasional yang dapat menjelaskan terjadinya perdagangan internasional. Suatu negara yang mempunyai keunggulan komparatif akan mampu menggunakan metode yang ilmiah. bersaing dengan produk dari negara lain. 
Negara produsen akan mendapatkan keuntungan jika memproduksi barang yang memiliki keunggulan komparatif. Namun, jika tidak memiliki keunggulan komparatif, negara akan melakukan impor dari negara lain (Krugman \& Obstfeld, 2009). Hal inilah yang mendasari terjadinya perdagangan internasional.

Dalam perkembangannya, perdagangan internasional menjadi suatu hal yang tidak terelakkan bagi setiap negara. Tidak terkecuali negara Indonesia. Negara mendorong setiap industri untuk dapat bersaing dalam tingkat global. Dorongan tersebut di antaranya berupa fasilitas yang diberikan kepada perusahaan yang melakukan impor barang dan hasilnya bertujuan ekspor.

\section{b. Kawasan Berikat}

Kawasan berikat merupakan salah satu tempat penimbunan berikat yang digunakan untuk melakukan pengolahan bahan baku menjadi barang jadi dengan mendapatkan penangguhan bea masuk dan tidak dipungut pajak dalam rangka impor. Konsep pengolahan barang di kawasan berikat berlaku untuk perusahaan yang mengolah bahan baku menjadi barang jadi. Berbagai jenis industri bisa mendapatkan fasilitas kawasan berikat. Umumnya jenis industri yang menerima fasilitas kawasan berikat adalah yang bergerak di bidang garmen, tekstil, sepatu atau alas kaki, plastik dan bahkan budi daya flora dan fauna. Sementara jenis investasi yang ada, dapat berupa penanaman modal asing, penanaman modal dalam negeri maupun campuran.

Perusahaan kawasan berikat yang melakukan impor bahan baku, tidak perlu membayar bea masuk dan pajak dalam rangka impor saat mengimpor bahan baku. Demikian pula ketika membeli bahan baku dari dalam negeri, mendapatkan fasilitas pajak tidak dipungut. Pajak pertambahan nilai dan pajak penghasilan atas pemasukan barang tersebut tidak dipungut.

Pengenaan tarif yang biasa dikenakan kepada barang impor, dihilangkan dalam skema impor oleh kawasan berikat. Dalam kegiatan ekonomi, penggunaan tarif dapat meningkatkan harga barang dibandingkan dengan harga dunia. Tarif diberlakukan dengan tujuan untuk menyeimbangkan harga dunia dengan harga dalam negeri agar produksi dalam negeri mampu bersaing dengan produk luar negeri yang diimpor. Dengan dikenakannya tarif, barang impor menjadi bertambah mahal harganya.

Gambar II.1 merupakan kurva pengaruh dikenakannya tarif dalam kegiatan impor (Mankiw, 2016). Dalam 
gambar tersebut, dapat dilihat bahwa ketika terjadi perdagangan internasional dan negara memberlakukan tarif impor, maka harga akan berada pada posisi garis horizontal berwarna merah. Perusahaan kawasan berikat mendapatkan fasilitas penangguhan bea masuk dan tidak dipungut pajak dalam rangka impor sehingga tidak dikenakan tarif impor. Sesuai dengan gambar tersebut, kawasan berikat mendapatkan harga pada garis horizontal berwarna biru atau harga sebelum ada tarif.

\section{Gambar II.1 Pengaruh Tarif Impor}

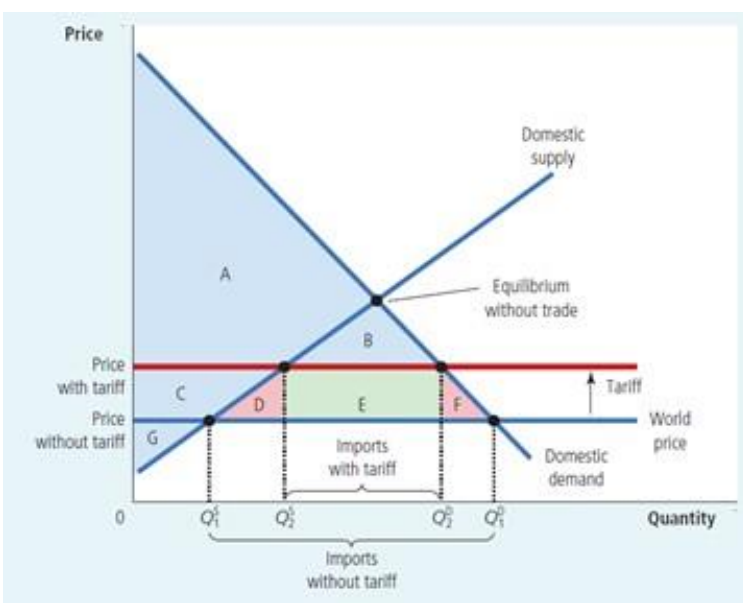

Sumber: Mankiw (2016)

Dengan keadaan tersebut, kawasan berikat mendapatkan harga bahan baku yang berasal dari luar negeri lebih murah dibandingkan dengan pesaing yang bukan merupakan perusahaan kawasan berikat. Perusahaan mendapatkan kesempatan untuk memenangkan persaingan karena mendapatkan bahan baku yang lebih murah. Lebih jauh lagi, perusahaan dapat bersaing dalam level global dengan melakukan ekspor produksinya. Dengan keadaan seperti itu, diharapkan kinerja dan keuntungan perusahaan menjadi lebih baik.

Perusahaan kawasan berikat utamanya didorong untuk tujuan ekspor. Hasil dari kegiatan ekspor berupa devisa bagi negara eksportir. Hal itu mengakibatkan adanya aliran uang yang masuk dari luar negeri ke dalam negeri. Negara mendapatkan keuntungan dari masuknya aliran dana tersebut. Primandari (2017) menyatakan bahwa nilai ekspor akan berpengaruh positif terhadap tingkat pertumbuhan ekonomi. Senada dengan hal tersebut, Balassa (1978) telah meneliti sebelas negara dengan hasil bahwa ekspor berkaitan dengan pertumbuhan suatu negara.

Sementara itu, menurut Arfiani (2019), yang melakukan penelitian tentang hubungan antara ekspor, impor, nilai tukar dan pertumbuhan ekonomi di Indonesia menyatakan bahwa kegiatan ekspor di Indonesia sangat dipengaruhi oleh kegiatan impor. Penyebab keadaan tersebut adalah penggunaan bahan baku hasil produksi di Indonesia yang berasal dari impor sehingga antara ekspor dan impor menjadi saling terkait. Hal tersebut sejalan dengan penelitian oleh Situmorang 
(2020), yang menyatakan adanya kontribusi perusahaan penerima fasilitas kawasan berikat dan kemudahan impor tujuan ekspor yang mencapai $47,23 \%$ dari total ekspor Indonesia. Perusahaan penerima fasilitas tersebut melakukan impor bahan baku untuk diolah dan diekspor.

Bagi perusahaan, ekspor merupakan kegiatan memperluas pasar. Dengan begitu diharapkan permintaan barang akan bertambah. Hal tersebut terjadi karena dimungkinkan muncul permintaan dari pasar yang sebelumnya belum ada, misalnya dari negara-negara di seluruh dunia. Selain itu, jika harga pada pasar dunia lebih besar daripada harga pada pasar domestik, perusahaan akan mendapatkan keuntungan yang lebih besar. Hal tersebut sesuai dengan penelitian yang dilakukan oleh Fryges \& Wagner (2010). Dalam penelitian yang dilakukan di Jerman tersebut diungkapkan bahwa terdapat perbedaan yang signifikan pada tingkat keuntungan perusahaan yang melakukan ekspor dan tidak melakukan ekspor. Sementara penelitian di turki yang dilakukan oleh Esmeray \& Esmeray (2016), menyatakan bahwa ekspor memberikan pengaruh yang positif terhadap keuntungan.

\section{c. Keuntungan Perusahaan}

Keuntungan merupakan salah satu tolok ukur kesuksesan perusahaan. Secara mudah, keuntungan dapat dihitung dengan mengurangkan biaya dengan total pendapatan. Perusahaan yang mempunyai keuntungan besar akan mempunyai lebih banyak kesempatan yang dapat digunakan untuk mengembangkan kegiatannya. Dengan keuntungan yang memadai, perusahaan mempunyai kemampuan bersaing yang lebih baik dibandingkan dengan yang lain. Perusahaan juga akan mampu bertahan dalam masa sulit.

Untuk mengukur keuntungan perusahaan juga dapat diwujudkan dalam suatu ukuran tertentu. Ukuran tersebut dikenal dengan rasio profitabilitas. Rasio profitabilitas merupakan rasio untuk menilai kemampuan perusahaan dalam mendapatkan keuntungan (Kasmir, 2008). Beberapa perhitungan dalam rasio profitabilitas di antaranya adalah dengan metode net profit margin, ROE (return on equity), ROI (return on investment), dan EPS (earning per share). Namun, pada umumnya perhitungan keuntungan merupakan hasil dari total pendapatan perusahaan dikurangi dengan total biaya yang dikeluarkan.

\begin{tabular}{llr}
\multicolumn{1}{c}{ Perusahaan } & berusaha & untuk \\
mendapatkan & keuntungan & dengan \\
melakukan & penjualan & sebanyak-
\end{tabular}


banyaknya. Bagi perusahaan, kegiatan ekspor merupakan suatu kesempatan untuk menjual hasil produksinya ke pasar yang lebih luas. Dengan melakukan ekspor berarti perusahaan telah memperluas pangsa pasar keluar tidak hanya di dalam negara perusahaan tersebut. Menurut penelitian oleh Fryges \& Wagner (2010), diketahui bahwa terdapat hubungan antara ekspor dengan keuntungan perusahaan. Hal ini berarti dengan semakin besar nilai ekspor perusahaan, semakin besar pula tingkat keuntungan yang akan diperoleh. Sejalan dengan penelitian tersebut, Ekasari \& Baskara (2018) dalam penelitiannya mengungkapkan bahwa nilai ekspor berpengaruh positif dan signifikan terhadap profitabilitas perusahaan food and beverage di Bursa Efek Indonesia periode 2012-2016. Sementara itu, penelitian di Uganda menunjukkan bahwa perusahaan yang mendapatkan insentif pajak mempunyai kinerja yang lebih baik daripada perusahaan lain (Mayende, 2013).

\section{d. Penelitian terdahulu}

Beberapa penelitian terdahulu terkait dengan fasilitas kawasan berikat di antaranya dilakukan oleh Valentina (2019). Penelitian tersebut mengggunakan metode kualitatif deskriptif, dengan fokus penelitian untuk memperoleh gambaran pengawasan kawasan berikat serta pengaruh pemberian fasilitas ini bagi perusahaan. Kesimpulan yang didapatkan adalah bahwa perusahaan melakukan penghematan yang cukup besar pada saat menerima fasilitas kawasan berikat sehingga cukup baik pada arus kas perusahaan. Selain itu, juga terjadi penurunan jumlah prepaid taxes dari Rp51 miliar menjadi Rp16 miliar.

Octarina (2015), melakukan analisis perbedaan antara perlakuan bea dan cukai di kawasan berikat dengan perlakuan bea dan cukai di kawasan tidak berikat, serta dampaknya jika suatu kawasan ditetapkan sebagai kawasan berikat. Hasil penelitian menunjukkan bahwa fasilitas kawasan berikat menunjukkan pengaruh yang positif terhadap perkembangan suatu perusahaan.

Penelitian selanjutnya oleh Handayani (2015), yang berfokus untuk mendapatkan gambaran secara sistematis mengenai nilai pembelian bahan baku utama impor dan pembebanan beban pajak dan bea masuk dengan menggunakan fasilitas KITE dan apabila menggunakan kawasan berikat yang dilakukan selama tahun buku 2013 s.d. 2014 melalui analisis dokumen berupa laporan pembelian. Hasil penelitian menunjukkan bahwa 
perusahaan lebih menguntungkan jika memilih menjadi kawasan berikat.

Penelitian tentang fasilitas kepabeanan juga dilakukan oleh Nabila \& Sriyanto (2018). Fokus penelitian tersebut untuk memberikan bukti empiris terkait hubungan antara nilai fasilitas KITE, perubahan kebijakan KITE, nilai impor, dan nilai kurs mata uang terhadap nilai ekspor KITE. Hasil penelitian menunjukkan bahwa fasilitas KITE dan nilai kurs memberikan pengaruh positif dan signifikan terhadap nilai ekspor KITE.

Adiyanti (2012), melakukan penelitian untuk menganalisis pengaruh fasilitas pajak dan kawasan berikat dalam meningkatkan ekspor pada tahun 2009 s.d. 2011. Hasil penelitian menunjukkan bahwa fasilitas kawasan berikat mampu meningkatkan nilai ekspor.

Dalam penelitian yang dilakukan Khizazi (2020), diungkapkan bahwa semakin besar fasilitas yang diterima, dan semakin banyak intensitas ekspor akan membuat produktivitas perusahaan semakin tinggi. Namun, pada penelitian tersebut juga mengungkapkan terdapat $20 \%$ perusahaan kawasan berikat yang melaporkan diri mengalami kerugian.

Sementara itu, penelitian yang terkait dengan ekspor dan keuntungan perusahaan dilakukan oleh Fryges \&
Wagner (2010) yang menyebutkan bahwa semakin besar nilai ekspor perusahaan, semakin besar pula tingkat keuntungan yang akan diperoleh.

Dari beberapa penelitian terdahulu tersebut, dapat disimpulkan bahwa fasilitas kawasan berikat mampu meningkatkan nilai ekspor (Adiyanti, 2012) kemudian ekspor tersebut berpengaruh positif terhadap keuntungan (Ekasari \& Baskara, 2018; Fryges \& Wagner, 2010).

\section{METODE PENELITIAN}

Penelitian ini menggunakan data sekunder, yang diperoleh dari database KPPBC XYZ. Data yang digunakan merupakan data yang diperoleh dari survei dampak ekonomi pemberian fasilitas pada KPPBC XYZ di bawah pengawasannya pada tahun 2018 .

Data yang digunakan data bersifat cross section (terdapat 72 perusahaan) pada tahun 2018.

Karakteristik perusahaan diukur dari 5 variabel independen dan 1 variabel dependen. Variabel independen berjenis kategorik, yaitu dengan skala nominal dan ordinal, sedangkan variabel dependen berjenis numerik dengan skala rasio. Karakteristik perusahaan yang diukur yaitu: 
a. jenis industri penerima fasilitas. Data berjenis kategorik dengan skala data nominal (kelompok) yang terdiri dari garmen, tekstil, sepatu/kulit dan plastik/aksesoris/cetakan;

b. jenis investasi perusahaan penerima fasilitas. Data berjenis kategorik dengan skala data ordinal (kelompok dan peringkat) yang terdiri dari investasi dalam negeri, campuran dan asing.

c. umur pemberian fasilitas. Data berjenis kategorik dengan skala data ordinal (kelompok dan peringkat) yang terdiri dari $\leq 1$ tahun, 1-2 tahun, 2-3 tahun dan $>3$ tahun.

d. tingkat ekspor perusahaan penerima fasilitas. Data berjenis kategorik dengan skala data ordinal (kelompok dan peringkat) yang terdiri dari eskpor $\leq 50 \%, \quad 50 \%<$ ekspor $\leq 75 \%$, $75 \%<$ ekspor $\leq 99 \%$, dan $100 \%$ ekspor.

e. nilai pembebasan. Data berjenis kategorik dengan skala data ordinal (kelompok dan peringkat) yang terdiri dari kelompok persentase nilai pembebasan terhadap nilai ekspor, yaitu pembebasan $\leq 20 \%$, $20<$ pembebasan $\leq 40 \%$, pembebasan $>40 \%$.

f. Keuntungan perusahaan merupakan nilai keuntungan/kerugian perusahaan penerima fasilitas kawasan berikat. Data berjenis numerik dengan skala rasio.

Berdasarkan karakteristik data dan tujuan penelitian, maka metode penelitian yang digunakan adalah metode penelitian kuantitatif dengan teknik analisis data menggunakan analisis deskriptif, one-way analysis of variance (ANOVA) dan uji lanjut Tukey HSD atau Benferoni. Analisis dilakukan menggunakan software SPSS.

One-way analysis of variance (ANOVA) merupakan metode pengujian nilai tengah (pengaruh) tiga atau lebih populasi yang menganalisis varian sampel. Analisis varian satu arah digunakan dengan data yang dikategorikan dengan satu faktor (atau treatment), sehingga ada satu karakteristik yang digunakan untuk memisahkan data sampel menjadi kategori yang berbeda (Triola, 2015).

One-way analysis of variance (ANOVA) dapat disebut juga dengan analisis faktorial (Mattjik \& Sumertajaya, 2013). Percobaan faktorial dicirikan oleh perlakuan (variabel/faktor) yang merupakan komposisi dari semua kemungkinan kombinasi dari taraf-taraf dua faktor atau lebih (taraf: ukuran nilai yang diukur pada masing-masing variabel/faktor). 


\section{HASIL DAN PEMBAHASAN}

\section{a. Analisis Deskriptif}

Kawasan berikat yang berada di daerah XYZ atau di bawah pengawasan KPPBC XYZ berjumlah 72 perusahaan. Akan tetapi, karena keterbatasan ketersediaan data yang digunakan, perusahaan yang akan dianalisis hanya berjumlah 55 perusahaan.

\section{a.1. Deskriptif Jenis Industri dan}

\section{Keuntungan Perusahaan}

Berdasarkan Tabel IV.1, dari jenis industri tampak bahwa industri garmen merupakan industri yang paling dominan. Terdapat 33 perusahaan kawasan berikat merupakan perusahaan garmen dan 12 perusahaan merupakan perusahaan tekstil.

Terlihat dari 55 perusahaan yang medapatkan fasilitas kawasan berikat bahwa perusahaan yang mendapatkan keuntungan sebanyak 39 perusahaan $(70,9 \%)$ dan yang mengalami kerugian sebanyak 16 perusahaan (29.1\%). Dari 39 perusahaan yang mengalami keuntungan, terdiri dari industri garmen sebanyak $69,7 \%$, tekstil sebanyak 66,7\%, sepatu/kulit sebanyak 66,7\% dan industri plastik/aksesoris/cetakan sebanyak 85,7\%.

Tabel IV.1. Crosstab Jenis Industri Keuntungan Kawasan Berikat KPPBC XYZ Tahun 2018

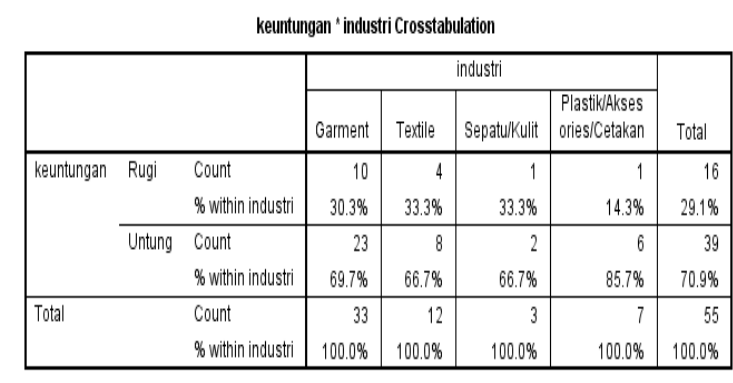

Sumber: diolah

Tabel IV.1 dapat menjelaskan bahwa karakteristik jenis industri perusahaan kawasan berikat sebagian besar mengalami keuntungan.

\section{a.2. Deskriptif Jenis Investasi dan}

\section{Keuntungan Perusahaan}

Berdasarkan Tabel IV.2, jenis investasi terdiri dari investasi dalam negeri sebanyak 32 perusahaan, investasi asing 18 perusahaan, dan investasi campuran 5 perusahaan.

Tabel IV.2. Crosstab Jenis Investasi dan Keuntungan Kawasan Berikat

KPPBC XYZ Tahun 2018

\begin{tabular}{|c|c|c|c|c|c|c|}
\hline \multicolumn{7}{|c|}{ keuntungan * investasi Crosstabulation } \\
\hline & & & \multicolumn{3}{|c|}{ investasi } & \multirow[b]{2}{*}{ Total } \\
\hline & & & dalam negeri & campuran & asing & \\
\hline \multirow[t]{4}{*}{ keuntungan } & Rugi & Count & 7 & 1 & 8 & 16 \\
\hline & & $\%$ within investasi & $21.9 \%$ & $20.0 \%$ & $44.4 \%$ & $29.1 \%$ \\
\hline & Untung & Count & 25 & 4 & 10 & 39 \\
\hline & & $\%$ within investasi & $78.1 \%$ & $80.0 \%$ & $55.6 \%$ & $70.9 \%$ \\
\hline \multirow[t]{2}{*}{ Total } & & Count & 32 & 5 & 18 & 55 \\
\hline & & $\%$ within investasi & $100.0 \%$ & $100.0 \%$ & $100.0 \%$ & $100.0 \%$ \\
\hline
\end{tabular}

Sumber: diolah

Perusahaan kawasan berikat yang mendapatkan keuntungan dari jenis investasinya, 78,1\% merupakan investasi dalam negeri, 80,0\% investasi campuran, dan 55,6\% investasi asing. 
Tabel IV.2 dapat menjelaskan bahwa karakteristik jenis investasi perusahaan kawasan berikat sebagian besar mengalami keuntungan.

\section{a.3. Deskriptif Umur Fasilitas dan}

\section{Keuntungan Perusahaan}

Berdasarkan Tabel IV.3, kawasan berikat berumur $\leq 1$ tahun sebanyak 3 perusahaan, 1-2 tahun sebanyak 7 perusahaan, 2-3 tahun sebanyak 9 perusahaan dan $>3$ tahun sebanyak 36 perusahaan.

Tabel IV.3. Crosstab Umur fasilitas dengan Keuntungan Kawasan Berikat

KPPBC XYZ Tahun 2018

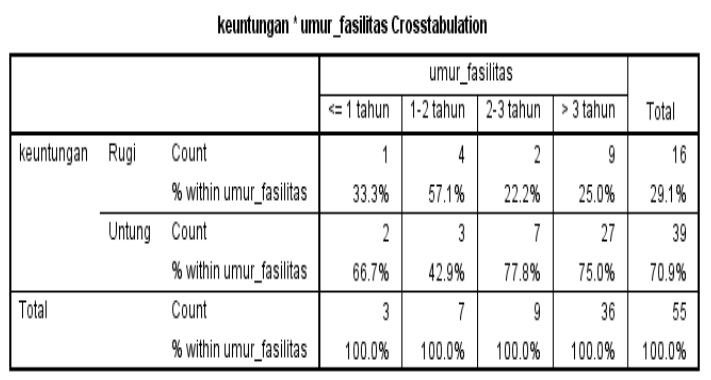

Sumber: diolah

Perusahaan kawasan berikat yang mendapatkan keuntungan dari umur fasilitas terdiri dari $66,7 \%$ berumur $\leq 1$ tahun, $42,9 \%$ berumur 1-2 tahun, 77,8\% berumur 2-3 tahun, dan $75,0 \%$ berumur $>3$ tahun.

Tabel IV.3 dapat menjelaskan bahwa karakteristik umur fasilitas perusahaan kawasan berikat sebagian besar mengalami keuntungan. a.4. Deskriptif Tingkat Ekspor dan Keuntungan Perusahaan

Berdasarkan Tabel IV.4, terdapat 4 perusahaan dengan tingkat ekspor $\leq 50 \%$, 7 perusahaan dengan tingkat ekspor $50 \%<$ ekspor $\leq 75 \%, 18$ perusahaan dengan tingkat ekspor $75 \%<$ ekspor $\leq 99 \%$, dan 26 perusahaan dengan tingkat ekspor $100 \%$.

Tabel IV.4. Crosstab Keuntungan dengan Tingkat Ekspor Kawasan Berikat KPPBC XYZ Tahun 2018

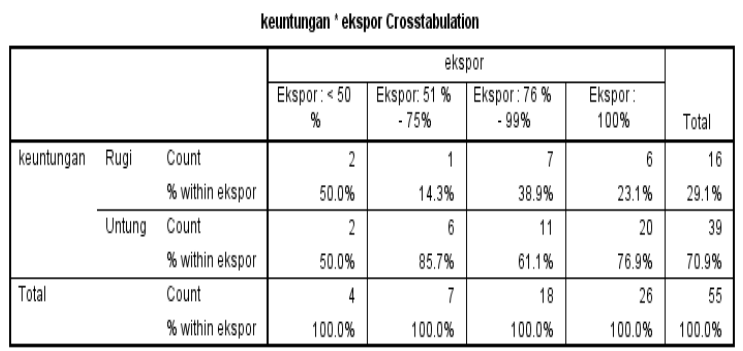

Sumber: diolah

Perusahaan kawasan berikat yang mendapatkan keuntungan dari tingkat ekspor terdiri dari $50 \%$ perusahaan dengan tingkat ekspor $\leq 50 \%, 85,7 \%$ perusahaan dengan tingkat ekspor $50 \%<$ ekspor $\leq 75 \%$, $61,1 \%$ perusahaan dengan tingkat ekspor $75 \%<$ ekspor $\leq 99 \%$, dan $76,9 \%$ perusahaan dengan tingkat ekspor $100 \%$.

Tabel IV.4 dapat menjelaskan bahwa karakteristik tingkat ekspor perusahaan kawasan berikat sebagian besar mengalami keuntungan.

\section{a.5. Deskriptif Pembebasan dan}

Keuntungan Perusahaan 
Berdasarkan Tabel IV.5, terdapat 37 perusahaan dengan pembebasan $\leq 20 \%, 9$ perusahaan dengan pembebasan $20 \%<$ pembebasan $\leq 40 \%, \quad$ dan $\quad 9$ perusahaan dengan pembebasan $>40 \%$. Tabel IV.5. Crosstab Pembebasan dengan Keuntungan Kawasan Berikat KPPBC XYZ Tahun 2018

\begin{tabular}{|c|c|c|c|c|c|c|}
\hline \multicolumn{7}{|c|}{ keuntungan ' pembebasan Crosstabulation } \\
\hline & & & \multicolumn{3}{|c|}{ pembebasan } & \multirow[b]{2}{*}{ Total } \\
\hline & & & $<=20 \mathrm{M}$ & $20 \mathrm{M}<x<=40 \mathrm{M}$ & $>40 \mathrm{M}$ & \\
\hline \multirow[t]{4}{*}{ keuntungan } & Rugi & Count & 10 & 1 & 5 & 16 \\
\hline & & $\%$ within pembebasan & $27.0 \%$ & $11.1 \%$ & $55.6 \%$ & $29.1 \%$ \\
\hline & Untung & Count & 27 & 8 & 4 & 39 \\
\hline & & $\%$ within pembebasan & $73.0 \%$ & $88.9 \%$ & $44.4 \%$ & $70.9 \%$ \\
\hline \multirow[t]{2}{*}{ Total } & & Count & 37 & 9 & 9 & 55 \\
\hline & & $\%$ within pembebasan & $100.0 \%$ & $100.0 \%$ & $100.0 \%$ & $100.0 \%$ \\
\hline
\end{tabular}

Perusahaan kawasan berikat yang mendapatkan keuntungan dari tingkat pembebasan terdiri dari $73,0 \%$ perusahaan dengan tingkat pembebasan $\leq 20 \%, 88,9 \%$ perusahaan dengan tingkat pembebasan $20 \%<$ pembebasan $\leq 40 \%, \quad$ dan $\quad 44,4 \%$ perusahaan dengan tingkat pembebasan $>40 \%$.

Tabel IV.5 dapat menjelaskan bahwa karakteristik tingkat pembebasan perusahaan kawasan berikat sebagian besar mengalami keuntungan.

e. One-way Analysis of Variance (ANOVA)/Analisis Faktorial dengan

\section{5 (lima) Faktor}

Treatment faktorial dicirikan oleh perlakuan yang merupakan komposisi dari semua kemungkinan kombinasi dari taraftaraf/level-level dua faktor atau lebih
(Mattjik \& Sumertajaya, 2013). Dalam analisis ini, peneliti menggunakan tingkat keyakinan 95\% $(\alpha=5 \%)$. Hipotesis yang akan dibuktikan untuk menjawab pertanyaan dan tujuan penelitian yaitu:

\section{b.1. Uji Pengaruh Variabel Jenis}

\section{Industri terhadap Keuntungan} Perusahaan.

Hipotesis dalam pengujian pengaruh jenis industri perusahaan kawasan berikat terhadap keuntungan perusahaan, yaitu:

$\mathrm{H}_{0.1}$ : Pengaruh jenis industri kawasan berikat terhadap keuntungan perusahaan sama.

$\mathrm{H}_{1.1}$ : Minimal ada satu jenis industri kawasan berikat yang mempunyai pengaruh berbeda terhadap keuntungan perusahaan.

\section{b.2. Uji Pengaruh Variabel Jenis}

\section{Investasi terhadap Keuntungan}

\section{Perusahaan.}

Hipotesis dalam pengujian pengaruh jenis investasi perusahaan kawasan berikat terhadap keuntungan perusahaan, yaitu:

$\mathrm{H}_{0.2}$ : Pengaruh jenis investasi kawasan berikat terhadap keuntungan perusahaan sama.

$\mathrm{H}_{1.2}$ : Minimal ada satu jenis investasi kawasan berikat yang mempunyai pengaruh berbeda terhadap keuntungan perusahaan. 
Vol. 5, No. 1, 2021

\section{b.3. Uji Pengaruh Variabel Umur}

Fasilitas terhadap Keuntungan

\section{Perusahaan.}

Hipotesis dalam pengujian pengaruh umur fasilitas perusahaan kawasan berikat terhadap keuntungan perusahaan, yaitu:

$\mathrm{H}_{0.3}$ : Pengaruh umur fasilitas kawasan berikat terhadap keuntungan perusahaan sama.

$\mathrm{H}_{1.3}$ : Minimal ada satu umur fasilitas kawasan berikat yang mempunyai pengaruh berbeda terhadap keuntungan perusahaan.

\section{b.4. Uji Pengaruh Variabel Tingkat}

Ekspor terhadap Keuntungan

\section{Perusahaan.}

Hipotesis dalam pengujian pengaruh tingkat ekspor perusahaan kawasan berikat terhadap keuntungan perusahaan, yaitu:
$\mathrm{H}_{0.4}$ : Pengaruh tingkat ekspor kawasan berikat terhadap keuntungan perusahaan sama.

$\mathrm{H}_{1.4}$ : Minimal ada satu tingkat ekspor kawasan berikat yang mempunyai pengaruh berbeda terhadap keuntungan perusahaan.

\section{b.5. Uji Pengaruh Variabel}

\section{Pembebasan terhadap Keuntungan} Perusahaan.

Hipotesis dalam pengujian pengaruh tingkat pembebasan perpajakan perusahaan kawasan berikat terhadap keuntungan perusahaan, yaitu:

$\mathrm{H}_{0.5}$ : Pengaruh tingkat pembebasan perpajakan kawasan berikat terhadap keuntungan perusahaan sama.

$\mathrm{H}_{1.5}$ : Minimal ada satu tingkat pembebasan perpajakan kawasan berikat yang mempunyai pengaruh berbeda terhadap keuntungan perusahaan.

Tabel IV.6 One-way Analysis of Variance/Analisis Faktorial (General Linear Model)

\begin{tabular}{|c|c|c|c|c|c|}
\hline Dependent Variable: & nilai_keuntungan & & & & \\
\hline Source & Type III Sum of Squares & df & Mean Square & $\mathrm{F}$ & Sig. \\
\hline Corrected Model & $1120966289805044300000000.000^{a}$ & 38 & 29499112889606400000000.000 & 24.312 & .000 \\
\hline Intercept & 108142659980030000000000.000 & 1 & 108142659980030000000000.000 & 89.127 & .000 \\
\hline industri & 2274368760381280000000.000 & 3 & 758122920127093000000.000 & .625 & .609 \\
\hline investasi & 60636430068949300000000.000 & 2 & 30318215034474700000000.000 & 24.987 & .000 \\
\hline umur_fasilitas & 83579544907945300000000.000 & 3 & 27859848302648400000000.000 & 22.961 & .000 \\
\hline ekspor & 6149502086892670000000.000 & 3 & 2049834028964220000000.000 & 1.689 & .209 \\
\hline pembebasan & 2596404689476350000000.000 & 2 & 1298202344738180000000.000 & 1.070 & .366 \\
\hline Corrected Total & 1140380021839830000000000.000 & 54 & & & \\
\hline
\end{tabular}

a. R Squared $=, 983$ (Adjusted R Squared $=, 943$ )

Sumber: diolah 
Berdasarkan Tabel IV.6, dapat disimpulkan terkait dengan hipotesis penelitian yaitu:

\section{1) Uji Pengaruh Variabel Jenis Industri}

terhadap Keuntungan Perusahaan.

Hipotesis:

$\mathrm{H}_{0.1}$ : Pengaruh jenis industri Kawasan berikat terhadap keuntungan perusahaan sama.

$\mathrm{H}_{1.1}$ : Minimal ada satu jenis industri kawasan berikat yang mempunyai pengaruh berbeda terhadap keuntungan perusahaan.

Nilai signifikansi jenis industri 0,609 $(>\alpha: 5 \%)$, belum cukup bukti untuk menolak $\mathrm{H}_{0.1}$ sehingga dalam tingkat kepercayaan 95\% pengaruh jenis industri kawasan berikat (garmen, tekstil, sepatu/kulit, dan plastik/aksesoris/cetakan) terhadap keuntungan perusahaan sama. Hal ini berarti semua industri dapat merasakan manfaat pemberian fasilitas kawasan berikat terhadap keuntungan perusahaan. Oleh karena itu, setiap industri dapat saja mengajukan menjadi perusahaan penerima fasilitas dalam kawasan berikat.

\section{2) Uji Pengaruh Variabel Jenis} Investasi terhadap Keuntungan Perusahaan.

Hipotesis:
$\mathrm{H}_{0.2}$ : Pengaruh jenis investasi kawasan berikat terhadap keuntungan perusahaan sama.

$\mathrm{H}_{1.2}$ : Minimal ada satu jenis investasi kawasan berikat yang mempunyai pengaruh berbeda terhadap keuntungan perusahaan.

Nilai signifikansi jenis investasi 0,000 ( $<\alpha: 5 \%$ ), cukup bukti untuk menolak $\mathrm{H}_{0.2}$ sehingga dalam tingkat kepercayaan 95\% pengaruh jenis investasi kawasan berikat (dalam negeri, campuran, dan asing) terhadap keuntungan perusahaan berbeda. Hal ini berarti industri dapat mempertimbangkan jenis investasi ketika akan memasuki kawasan berikat.

\section{3) Uji Pengaruh Variabel Umur} Fasilitas terhadap Keuntungan Perusahaan.

Hipotesis:

$\mathrm{H}_{0.3}$ : Pengaruh umur fasilitas kawasan berikat terhadap keuntungan perusahaan sama.

$\mathrm{H}_{1.3}$ : Minimal ada satu umur fasilitas kawasan berikat yang mempunyai pengaruh berbeda terhadap keuntungan perusahaan.

Nilai signifikansi umur fasilitas 0,000 $(<\alpha: 5 \%)$, cukup bukti untuk menolak $\mathrm{H}_{0.3}$ sehingga dalam tingkat kepercayaan 95\% pengaruh umur fasilitas kawasan berikat ( $\leq 1$ tahun, 1-2 tahun, 2-3 tahun dan $>3$ 
tahun) terhadap keuntungan perusahaan berbeda. Hal ini berarti industri yang masuk ke kawasan berikat perlu penyesuaian proses bisnis perusahaan sehingga umur fasilitas ini akan memengaruhi keuangan perusahaan yang pada akhirnya pada keuntungan perusahaan.

\section{4) Uji Pengaruh Variabel Tingkat}

\section{Ekspor terhadap Keuntungan}

\section{Perusahaan.}

Hipotesis:

$\mathrm{H}_{0.4}$ : Pengaruh tingkat ekspor kawasan berikat terhadap keuntungan perusahaan sama.

$\mathrm{H}_{1.4}$ : Minimal ada satu tingkat ekspor kawasan berikat yang mempunyai pengaruh berbeda terhadap keuntungan perusahaan.

Nilai signifikansi tingkat ekspor 0,209 $(>\alpha: 5 \%)$, belum cukup bukti untuk menolak $\mathrm{H}_{0.4}$ sehingga dalam tingkat kepercayaan $95 \%$ pengaruh tingkat ekspor kawasan berikat $(\leq 50 \%$, $50 \%<$ ekspor $\leq 75 \%, \quad 75 \%<$ ekspor $\leq 99 \%$, dan $100 \%$ ekspor) terhadap keuntungan perusahaan sama. Hal ini berarti industri kawasan berikat dengan tingkat ekspor berapa pun akan mendapatkan manfaat berupa keuntungan perusahaan.

\section{5) Uji Pengaruh Variabel Pembebasan} terhadap Keuntungan Perusahaan.
Hipotesis:

$\mathrm{H}_{0.5}$ : Pengaruh tingkat pembebasan perpajakan kawasan berikat terhadap keuntungan perusahaan sama.

$\mathrm{H}_{1.5}$ : Minimal ada satu tingkat pembebasan perpajakan kawasan berikat yang mempunyai pengaruh berbeda terhadap keuntungan perusahaan.

Nilai signifikansi tingkat ekspor 0,366 $(>\alpha: 5 \%)$, belum cukup bukti untuk menolak $\mathrm{H}_{0.5}$ sehingga dalam tingkat kepercayaan $95 \%$ pengaruh tingkat pembebasan kawasan berikat $(\leq 20 \%$, $20<$ pembebasan $\leq 40 \%, \quad$ pembebasan $>40 \%$ ) terhadap keuntungan perusahaan sama. Hal ini berarti industri kawasan berikat dengan tingkat pembebasan berapa pun akan mendapatkan manfaat berupa keuntungan perusahaan. Hal ini sejalan dengan penelitian-penelitian terdahulu bahwa kawasan berikat memberikan pengaruh terhadap keuangan perusahaan dan secara teori ekonomi bahwa dengan adanya pembebasan perpajakan maka akan mengurangi biaya perusahaan.

a. Analisis

\section{Benferroni/Tukey}

(Perbedaan Nilai Tengah

\section{Perlakuan/Faktor)}

Dari hasil uji hipotesis one-way analysis of variance (ANOVA)/analisis faktorial dengan lima faktor/variabel di atas, variabel yang terbukti terdapat 
Vol. 5, No. 1, 2021

perbedaan pengaruh masing-masing tukey/benferoni untuk mengetahui karakteristik perusahaan terhadap karakteristik variabel yang pengaruhnya keuntungan perusahaan kemudian berbeda. Pengujian dilakukan terhadap dilakukan uji lanjut dengan uji variabel jenis investasi dan umur fasilitas.

Tabel IV.7 Hasil Uji Tukey dan Bonferroni pada Jenis Investasi

\begin{tabular}{|c|c|c|c|c|c|c|c|}
\hline \multicolumn{8}{|c|}{ Multiple Comparisons } \\
\hline & \multirow[b]{3}{*}{ (I) investasi } & \multirow[b]{3}{*}{ (J) investasi } & \multirow{3}{*}{$\begin{array}{c}\text { Mean } \\
\text { Difference (I- } \\
\mathrm{J})\end{array}$} & & & & \\
\hline & & & & \multirow[b]{2}{*}{ Std. Error } & \multirow[b]{2}{*}{ Sig. } & \multicolumn{2}{|c|}{$95 \%$ Confidence Interval } \\
\hline & & & & & & Lower Bound & Upper Bound \\
\hline \multirow[t]{6}{*}{ Tukey HSD } & dalam negeri & campuran & $-3.4807 \mathrm{E}+11^{n}$ & $1.67508 \mathrm{E}+10$ & .000 & $-3.9130 E+11$ & $-3.0485 E+11$ \\
\hline & & asing & $1.2829 \mathrm{E}+10$ & $1.02629 \mathrm{E}+10$ & .442 & $-1.3652 E+10$ & $3.9311 \mathrm{E}+10$ \\
\hline & campuran & dalam negeri & $3.4807 E+11^{*}$ & $1.67508 \mathrm{E}+10$ & .000 & $3.0485 \mathrm{E}+11$ & $3.9130 \mathrm{E}+11$ \\
\hline & & asing & $3.6090 \mathrm{E}+11^{*}$ & $1.76091 \mathrm{E}+10$ & .000 & $3.1546 \mathrm{E}+11$ & $4.0634 E+11$ \\
\hline & asing & dalam negeri & $-1.2829 \mathrm{E}+10$ & $1.02629 \mathrm{E}+10$ & .442 & $-3.9311 E+10$ & $1.3652 \mathrm{E}+10$ \\
\hline & & campuran & $-3.6090 \mathrm{E}+11^{*}$ & $1.76091 \mathrm{E}+10$ & .000 & $-4.0634 E+11$ & $-3.1546 \mathrm{E}+11$ \\
\hline \multirow[t]{6}{*}{ Bonferroni } & dalam negeri & campuran & $-3.4807 E+11^{n}$ & $1.67508 \mathrm{E}+10$ & .000 & $-3.9285 E+11$ & $-3.0330 E+11$ \\
\hline & & asing & $1.2829 \mathrm{E}+10$ & $1.02629 \mathrm{E}+10$ & .688 & $-1.4604 E+10$ & $4.0262 \mathrm{E}+10$ \\
\hline & campuran & dalam negeri & $3.4807 \mathrm{E}+11^{n}$ & $1.67508 \mathrm{E}+10$ & .000 & $3.0330 \mathrm{E}+11$ & $3.9285 \mathrm{E}+11$ \\
\hline & & asing & $3.6090 \mathrm{E}+11^{*}$ & $1.76091 \mathrm{E}+10$ & .000 & $3.1383 E+11$ & $4.0797 \mathrm{E}+11$ \\
\hline & asing & dalam negeri & $-1.2829 \mathrm{E}+10$ & $1.02629 \mathrm{E}+10$ & .688 & $-4.0262 E+10$ & $1.4604 E+10$ \\
\hline & & campuran & $-3.6090 E+11^{*}$ & $1.76091 \mathrm{E}+10$ & .000 & $-4.0797 E+11$ & $-3.1383 E+11$ \\
\hline
\end{tabular}

Sumber: diolah 
Tabel IV.8 Hasil Uji Tukey dan Bonferroni pada Umur Fasilitas Multiple Comparisons

Dependent Variable: nilai_keuntungan

\begin{tabular}{|c|c|c|c|c|c|c|c|}
\hline & (I) umur_fasilitas & (J) umur_fasilitas & $\begin{array}{c}\text { Mean } \\
\text { Difference (I- } \\
\mathrm{J})\end{array}$ & Std. Error & Sig. & \multicolumn{2}{|c|}{$95 \%$ Confidence Interval } \\
\hline \multirow[t]{8}{*}{ Tukey HSD } & $<=1$ tahun & $1-2$ tahun & $-7.7704 \mathrm{E}+10^{x}$ & $2.40373 E+10$ & .024 & $-1.4648 \mathrm{E}+11$ & -8933179976 \\
\hline & & $>3$ tahun & $-2.1849 E+10$ & $2.09322 \mathrm{E}+10$ & .727 & $-8.1736 \mathrm{E}+10$ & $3.8039 E+10$ \\
\hline & 1-2 tahun & $<=1$ tahun & $7.7704 \mathrm{E}+10^{\star}$ & $2.40373 \mathrm{E}+10$ & .024 & 8933179976 & $1.4648 \mathrm{E}+11$ \\
\hline & & $>3$ tahun & $5.5855 \mathrm{E}+10^{x}$ & $1.43889 \mathrm{E}+10$ & .007 & $1.4688 \mathrm{E}+10$ & $9.7022 E+10$ \\
\hline & 2-3 tahun & $<=1$ tahun & $7.1206 \mathrm{E}+10^{n}$ & $2.32222 \mathrm{E}+10$ & .034 & 4766608930 & $1.3764 \mathrm{E}+11$ \\
\hline & & $1-2$ tahun & -6498475216 & $1.75543 \mathrm{E}+10$ & .982 & $-5.6722 E+10$ & $4.3725 E+10$ \\
\hline & & $>3$ tahun & $4.9357 \mathrm{E}+10^{\pi}$ & $1.29816 \mathrm{E}+10$ & .008 & $1.2216 \mathrm{E}+10$ & $8.6498 \mathrm{E}+10$ \\
\hline & $>3$ tahun & $<=1$ tahun & $2.1849 E+10$ & $2.09322 \mathrm{E}+10$ & .727 & $-3.8039 E+10$ & $8.1736 \mathrm{E}+10$ \\
\hline \multirow{9}{*}{ Bonferroni } & & 2-3 tahun & $-7.1206 \mathrm{E}+10^{x}$ & $2.32222 \mathrm{E}+10$ & .044 & $-1.4107 E+11$ & -1345654293 \\
\hline & & $>3$ tahun & $-2.1849 \mathrm{E}+10$ & $2.09322 \mathrm{E}+10$ & 1.000 & $-8.4820 E+10$ & $4.1122 \mathrm{E}+10$ \\
\hline & 1-2 tahun & $<=1$ tahun & $7.7704 \mathrm{E}+10^{*}$ & $2.40373 \mathrm{E}+10$ & .031 & 5392155514 & $1.5002 \mathrm{E}+11$ \\
\hline & & 2-3 tahun & 6498475216 & $1.75543 \mathrm{E}+10$ & 1.000 & $-4.6311 E+10$ & $5.9308 \mathrm{E}+10$ \\
\hline & & $>3$ tahun & $5.5855 \mathrm{E}+10^{\star}$ & $1.43889 \mathrm{E}+10$ & .008 & $1.2569 \mathrm{E}+10$ & $9.9142 \mathrm{E}+10$ \\
\hline & $2-3$ tahun & $<=1$ tahun & $7.1206 \mathrm{E}+10^{\pi}$ & $2.32222 \mathrm{E}+10$ & .044 & 1345654293 & $1.4107 E+11$ \\
\hline & & 1-2 tahun & -6498475216 & $1.75543 \mathrm{E}+10$ & 1.000 & $-5.9308 E+10$ & $4.6311 \mathrm{E}+10$ \\
\hline & & $>3$ tahun & $4.9357 \mathrm{E}+10^{\star}$ & $1.29816 \mathrm{E}+10$ & .009 & $1.0304 E+10$ & $8.8410 E+10$ \\
\hline & $>3$ tahun & $<=1$ tahun & $2.1849 \mathrm{E}+10$ & $2.09322 \mathrm{E}+10$ & 1.000 & $-4.1122 E+10$ & $8.4820 \mathrm{E}+10$ \\
\hline
\end{tabular}

Based on observed means.

The error term is Mean Square(Error) $=1213358252174170000000,000$.

*. The mean difference is significant at the 0,05 level.

Sumber: diolah

1. Uji Pengaruh Jenis Investasi campuran yaitu $0,000 \quad(<\alpha: 5 \%)$, cukup (Dalam Negeri, Campuran, dan bukti untuk menolak $\mathrm{H}_{0.6}$ sehingga Asing) terhadap Keuntungan terdapat perbedaan pengaruh investasi Perusahaan.

1) Hipotesis investasi dalam negeri dengan investasi campuran

$\mathrm{H}_{0.6}$ : Pengaruh investasi dalam negeri sama dengan investasi campuran.

$\mathrm{H}_{1.6}$ : Pengaruh investasi dalam negeri berbeda dengan investasi campuran.

Nilai sig. hasil uji Bonferroni antara dalam negeri dan investasi campuran dalam perusahaan kawasan berikat. Dengan nilai mean diff antara dalam negeri dan campuran bernilai negatif artinya investasi dalam negeri memberikan pengaruh terhadap keuntungan perusahaan lebih kecil dibandingkan investasi campuran. investasi dalam negeri dan investasi 


\section{2) Hipotesis investasi dalam negeri} dengan investasi asing

$\mathrm{H}_{0.7}$ : Pengaruh investasi dalam negeri sama dengan asing.

$\mathrm{H}_{1.7}$ : Pengaruh investasi dalam negeri berbeda dengan investasi asing.

Nilai sig. hasil uji Bonferroni antara investasi dalam negeri dan investasi asing yaitu $0,688(>\alpha: 5 \%)$, belum cukup bukti untuk menolak $\mathrm{H}_{0.7}$ sehingga tidak terdapat perbedaan pengaruh investasi dalam negeri dan investasi asing dalam perusahaan kawasan berikat.

\section{3) Hipotesis investasi campuran dengan investasi asing}

$\mathrm{H}_{0.8}$ : Pengaruh investasi campuran sama dengan investasi asing.

$\mathrm{H}_{1.8}$ : Pengaruh investasi campuran berbeda dengan investasi asing.

Nilai sig. hasil uji Bonferroni antara investasi campuran dan investasi asing yaitu $0.000(<\alpha: 5 \%)$, cukup bukti untuk menolak $\mathrm{H}_{0.8}$ sehingga terdapat perbedaan pengaruh investasi campuran dan investasi asing dalam perusahaan kawasan berikat. Dengan nilai mean diff antara campuran dan asing bernilai positif, artinya investasi campuran memberikan pengaruh terhadap keuntungan perusahaan lebih besar dibandingkan investasi asing.

Dari ketiga uji di atas, dapat disimpulkan bahwa investasi campuran mempunyai pengaruh lebih besar positif dibandingkan investasi dalam negeri dan investasi asing terhadap keuntungan perusahaan.

Tabel IV.9 Kesimpulan Uji Benferroni untuk Jenis Investasi

\begin{tabular}{|c|c|c|c|c|}
\hline (i) & (j) & $\begin{array}{c}\text { Mean Diff } \\
\text { (i)-(i) } \\
\end{array}$ & Sig. & Keputusan \\
\hline dalam negeri & campuran & negatif & 0.000 & campuran > dalam negeri \\
\hline dalam negeri & asing & positif & 0.442 & dalam negeri = asing \\
\hline campuran & asing & positif & 0.000 & campuran > asing \\
\hline Kesimpulan & & & & $\begin{array}{l}\text { campuran memberikan pengaruh lebih } \\
\text { besar terhadap keuntungan perusahaan }\end{array}$ \\
\hline
\end{tabular}

Sumber: diolah

2. Uji Pengaruh Umur Fasilitas ( $\leq 1$ Tahun, 1-2 Tahun, 2-3 Tahun dan >3 Tahun) terhadap Keuntungan Perusahaan

\section{1) Hipotesis umur fasilitas $\leq 1$ tahun dengan 1-2 tahun}

$\mathrm{H}_{0.9}$ : Pengaruh umur fasilitas $\leq 1$ tahun sama dengan 1-2 tahun.

$\mathrm{H}_{1.9}$ : Pengaruh umur fasilitas $\leq 1$ tahun berbeda dengan 1-2 tahun.

Nilai sig. hasil uji Bonferroni antara umur fasilitas $\leq 1$ tahun dan 1-2 tahun yaitu $0.031(<\alpha: 5 \%)$, cukup bukti untuk menolak $\mathrm{H}_{0.9}$ sehingga terdapat perbedaan pengaruh umur fasilitas $\leq 1$ tahun dengan 1-2 tahun dalam perusahaan kawasan berikat. Dengan nilai mean diff bernilai negatif artinya umur fasilitas $\leq 1$ tahun memberikan pengaruh terhadap 
keuntungan perusahaan lebih kecil dibandingkan 1-2 tahun. Hal ini dapat dimungkinkan karena perusahaan ketika mulai memasuki kawasan berikat tentu saja harus mempersiapkan proses bisnis dan sarana/prasarana perusahaan sesuai ketentuan perusahaan dalam kawasan berikat.

\section{2) Hipotesis umur fasilitas $\leq 1$ tahun} dengan 2-3 tahun

$\mathrm{H}_{0.10}$ : Pengaruh umur fasilitas $\leq 1$ tahun sama dengan 2-3 tahun.

$\mathrm{H}_{1.10}$ : Pengaruh umur fasilitas $\leq 1$ tahun berbeda dengan 2-3 tahun.

Nilai sig. hasil uji Bonferroni antara umur fasilitas $\leq 1$ tahun dan 2-3 tahun, yaitu $0,044(<\alpha: 5 \%)$, cukup bukti untuk menolak $\mathrm{H}_{0.10}$ sehingga terdapat perbedaan pengaruh umur fasilitas $\leq 1$ tahun dengan 2-3 tahun dalam perusahaan kawasan berikat. Dengan nilai mean diff bernilai negatif artinya umur fasilitas $\leq 1$ tahun memberikan pengaruh terhadap keuntungan perusahaan lebih kecil dibandingkan 2-3 tahun. Hal ini dapat dimungkinkan karena perusahaan baru saja memasuki kawasan berikat.

\section{3) Hipotesis umur fasilitas $\leq \mathbf{1}$ tahun} dengan $>3$ tahun

$\mathrm{H}_{0.11}$ : Pengaruh umur fasilitas $\leq 1$ tahun sama dengan $>3$ tahun.
$\mathrm{H}_{1.11}$ : Pengaruh umur fasilitas $\leq 1$ tahun berbeda dengan $>3$ tahun.

Nilai sig. hasil uji Bonferroni antara umur fasilitas $\leq 1$ tahun dan $>3$ tahun yaitu 1.000/Uji Tukey 0.727 (>a:5\%), belum cukup bukti untuk menolak $\mathrm{H}_{0.11}$ sehingga pengaruh umur fasilitas $\leq 1$ tahun dengan $>3$ tahun dalam perusahaan kawasan berikat tidak berbeda.

4) Hipotesis umur fasilitas 1-2 tahun dengan 2-3 tahun

$\mathrm{H}_{0.12}$ : Pengaruh umur fasilitas 1-2 tahun sama dengan 2-3 tahun.

$\mathrm{H}_{1.12}$ : Pengaruh umur fasilitas 1-2 tahun berbeda dengan 2-3 tahun.

Nilai sig. hasil uji Bonferroni antara umur fasilitas 1-2 tahun dengan 2-3 tahun yaitu 1.000/Uji Tukey 0.982 (> $>$ :5\%), belum cukup bukti untuk menolak $\mathrm{H}_{0.12}$ sehingga pengaruh umur fasilitas 1-2 tahun dengan 2-3 tahun dalam perusahaan kawasan berikat tidak berbeda.

\section{5) Hipotesis umur fasilitas 1-2 tahun dengan > 3 tahun}

$\mathrm{H}_{0.13}$ : Pengaruh umur fasilitas 1-2 tahun sama dengan $>3$ tahun.

$\mathrm{H}_{1.13}$ : Pengaruh umur fasilitas 1-2 tahun berbeda dengan $>3$ tahun.

Nilai sig. hasil uji Bonferroni antara umur fasilitas 1-2 tahun dengan $>3$ tahun yaitu $0.008(<\alpha: 5 \%)$, cukup bukti untuk menolak $\mathrm{H}_{0.13}$ sehingga pengaruh umur 
fasilitas 1-2 tahun berbeda dengan >3 tahun dalam perusahaan kawasan berikat.

Dengan nilai mean diff bernilai positif artinya umur fasilitas 1-2 tahun memberikan pengaruh terhadap keuntungan perusahaan lebih besar dibandingkan $>3$ tahun.

\section{6) Hipotesis umur fasilitas 2-3 tahun dengan $>3$ tahun}

$\mathrm{H}_{0.14}$ : Pengaruh umur fasilitas 2-3 tahun sama dengan $>3$ tahun.

$\mathrm{H}_{1.14}$ : Pengaruh umur fasilitas $2-3$ tahun berbeda dengan $>3$ tahun.

Nilai sig. hasil uji Bonferroni antara umur fasilitas 2-3 tahun dengan $>3$ tahun yaitu $0.009(<\alpha: 5 \%)$, cukup bukti untuk menolak $\mathrm{H}_{0.14}$ sehingga pengaruh umur fasilitas 2-3 tahun berbeda dengan >3 tahun dalam perusahaan kawasan berikat.

Dengan nilai mean diff bernilai positif artinya umur fasilitas 2-3 tahun memberikan pengaruh terhadap keuntungan perusahaan lebih besar dibandingkan $>3$ tahun.

Tabel IV.10 Kesimpulan Uji Benferroni untuk Umur Fasilitas

\begin{tabular}{ll|lll}
\hline \multicolumn{1}{c}{ (i) } & (j) & $\begin{array}{c}\text { Mean Diff } \\
\text { (i)-(j) }\end{array}$ & Sig. & \multicolumn{1}{c}{ Keputusan } \\
\hline \hline$<=1$ tahun & $1-2$ tahun & negatif & 0.031 & $<=1$ tahun $<1-2$ tahun \\
\hline$<=1$ tahun & $2-3$ tahun & negatif & 0.044 & $<=1$ tahun $<2-3$ tahun \\
\hline$<=1$ tahun & $>3$ tahun & negatif & 1.000 & $<=1$ tahun $=>3$ tahun \\
\hline $1-2$ tahun & $2-3$ tahun & positif & 1.000 & $1-2$ tahun $=2-3$ tahun \\
\hline $1-2$ tahun & $>3$ tahun & positif & 0.008 & $1-2$ tahun $>>3$ tahun \\
\hline $2-3$ tahun & $>3$ tahun & positif & 0.009 & $2-3$ tahun $>>3$ tahun \\
\hline \hline & & & & umur fasilitas $1-2$ tahun dan 2-3 tah \\
Kesimpulan & & & & memberikan pengaruh yang lebih bi \\
& & & & terhadap keuntungan perusahaan \\
\hline
\end{tabular}

Sumber: diolah

Berdasarkan hasil pengujian di atas (Tabel IV.10), dapat disimpulkan bahwa umur fasilitas 1-2 tahun dan 2-3 tahun memberikan pengaruh lebih besar terhadap keuntungan perusahaan. Umur fasilitas $\leq 1$ tahun lebih rendah pengaruhnya terhadap keuntungan perusahaan, hal ini mengindikasikan bahwa ketika perusahaan ingin masuk ke kawasan berikat, diharapkan perusahaan sudah mempersiapkan sarana dan prasarana serta proses bisnis sebagaimana ketentuan dari kawasan berikat.

\section{SIMPULAN DAN SARAN/ REKOMENDASI}

Kawasan berikat merupakan salah satu fasilitas kepabeanan yang diberikan kepada para pengusaha dengan mendapatkan fasilitas fiskal berupa pembebasan perpajakan. Teori ekonomi sudah membuktikan bahwa pembebasan perpajakan akan mengurangi cost dari perusahaan sehingga akan memengaruhi dari keuangan perusahaan yang salah satunya tercermin dalam keuntungan perusahaan. Beberapa penelitian terdahulu sudah membuktikan secara empiris bahawa kawasan berikat memengaruhi keuangan perusahaan.

Berdasrkan hasil analisis deskriptif, sebagian besar perusahaan kawasan 
berikat memperoleh manfaat berupa keuntungan perusahaan. Baik dari jenis industri, jenis investasi, umur fasilitas, tingkat ekspor dan tingkat pembebasan.

Berdasarkan hasil uji factorial, dapat dibuktikan bahwa:

1. Pengaruh jenis industri (garmen, tekstil, $\quad$ sepatu/kulit, dan plastik/aksesoris/cetakan) kawasan berikat terhadap keuntungan perusahaan adalah sama.

2. Terdapat perbedaan pengaruh jenis investasi (dalam negeri, campuran dan asing) kawasan berikat terhadap keuntungan perusahaan.

3. Terdapat perbedaan pengaruh umur fasilitas ( $\leq 1$ tahun, 1-2 tahun, 2-3 tahun dan $>3$ tahun) kawasan berikat terhadap keuntungan perusahaan.

4. Pengaruh tingkat ekspor $(\leq 50 \%$, $50 \%<$ ekspor $\leq 75 \%$, $75 \%<$ ekspor $\leq 99 \%$, dan $100 \%$ ekspor) perusahaan kawasan berikat terhadap keuntungan perusahaan adalah sama.

5. Pengaruh tingkat pembebasan $(\leq 20 \%$, $20<$ pembebasan $\leq 40 \%$, pembebasan $>40 \%$ ) perusahaan kawasan berikat terhadap keuntungan perusahaan adalah sama.

Berdasarkan uji faktorial tersebut, uji Bonferroni membuktikan:
1. Terdapat perbedaan pengaruh antara jenis investasi dalam negeri dengan investasi campuran terhadap keuntungan perusahaan;

2. Terdapat perbedaan pengaruh antara jenis investasi campuran dengan investasi asing terhadap keuntungan perusahaan;

3. Terdapat perbedaan pengaruh antara umur fasilitas $\leq 1$ tahun dengan 1-2 tahun terhadap keuntungan perusahaan;

4. Terdapat perbedaan pengaruh antara umur fasilitas $\leq 1$ tahun dengan 2-3 tahun terhadap keuntungan perusahaan;

5. Terdapat perbedaan pengaruh antara umur fasilitas 1-2 tahun dengan $>3$ tahun terhadap keuntungan perusahaan;

6. Terdapat perbedaan pengaruh antara umur fasilitas 2-3 tahun dengan >3 tahun terhadap keuntungan perusahaan; Dengan hasil penelitian ini, dapat dijadikan mitigasi risiko bagi perusahaan yang akan memasuki Kawasan berikat sehingga dapat memaksimalkan keuntungan perusahaan.

Selanjutnya dapat dilakukan penelitian pengaruh fasilitas terhadap keuntungan perusahaan untuk seluruh perusahaan kawasan berikat di seluruh Indonesia. Penelitian dilakukan dengan factor yang lebih beragam dan komprehensif. Hal tersebut supaya 
mendapatkan gambaran yang lebih menyeluruh terhadap perusahaan yang diberikan fasilitas ataupun dapat dilakukan perbandingan antara fasilitas kawasan berikat dengan fasilitas lainnya baik fiskal maupun nonfiskal.

\section{DAFTAR PUSTAKA}

Adiyanti, H. D. (2012). Analisis Fasilitas Perpajakan Pada Kawasan Berikat Terhadap Peningkatan Ekspor Tahun 2009-2011 Se-Karisidenan Surakarta.

Arfiani, I. S. (2019). Analisis Empiris Hubungan antara Ekspor, Impor, Nilai Tukar dan Pertumbuhan Ekonomi di Indonesia. Jurnal Ekonomi Pembangunan, 17(2), 8198.

Balassa, B. (1978). Export incentives and export performance in developing countries: A comparative analysis. Review of World Economics, 114(1), 24-61.

Ekasari, N. P., \& Baskara, I. G. K. (2018). Nilai Tukar, Nilai Ekspor, Dan Pertumbuhan Ekonomi Terhadap Profitabilitas Eksportir Food and Beverage Di Bei. E-Jurnal Manajemen, 7(8), 4181-4210.

Esmeray, A., \& Esmeray, M. (2016). The relationship between profit and export performance revisited: Evidence from Turkish companies. International Journal of Economics and Financial Issues, 6(3).

Fryges, H., \& Wagner, J. (2010). Exports and profitability: first evidence for German manufacturing firms. World Economy, 33(3), 399-423.

Kasmir. (2008). Analisis Laporan Keuangan. Raja Grafindo Persada.

Khizazi, A. (2020). Pengaruh Pemanfaatan Fasilitas Kawasan Berikat Terhadap Produktivitas
Perusahaan Manufaktur. Politeknik Keuangan Negara STAN.

Krugman, P. R., \& Obstfeld, M. (2009). International economics: Theory and policy. Pearson Education.

Mankiw, G. (2016). Principles Of Economics (8th ed.). Boston: Cengage Learning.

Mattjik, A. A., \& Sumertajaya, I. M. (2013). Perancangan percobaan dengan aplikasi SAS dan Minitab. PT Penerbit IPB Press.

Mayende, S. (2013). The effects of tax incentives on firm performance: Evidence from Uganda. J. Pol. \& L., 6,95 .

Nabila, A., \& Sriyanto, A. (2018). Analisis Pengaruh Fasilitas KITE Terhadap Nilai Ekspor (Studi Kasus Perusahaan Penerima Fasilitas KITE). Jurnal Perspektif Bea Dan Cukai, 2(1).

Octarina, Y. (2015). Analisis Perbandingan Perlakuan Bea Dan Cukai Di Kawasan Berikat Dengan Perlakuan Bea Dan Cukai Di Kawasan Non Berikat. Universitas Sumatera Utara.

Primandari, N. R. (2017). Pengaruh Nilai Ekspor Terhadap Pertumbuhan Ekonomi di Indonesia Periode Tahun 2000-2015. KOLEGIAL, 5(2), 183194.

Situmorang, E. (2020). FISCAL FACILITIES TO IMPROVE EXPORT PERFORMANCE. Dinasti International Journal of Economics, Finance \& Accounting, 1(1), 125133.

Triola, M. F. (2015). Essentials of Statistics (5th edition). Pearson.

Valentina, D. (2019). Analisis Pengawasan Serta Pengaruh Kawasan Berikat Terhadap Arus Kas, Beban Pajak Dan Aktivitas Ekspor Pt. Xyz. Jurnal Manajemen Bisnis Dan Kewirausahaan, 3(3). 